\title{
Evaluating the Quality of Maize Grains Stored in a Modified Metallic Silo
}

\author{
${ }^{1}$ Oniya, O. O., ${ }^{2}$ Fashina, A. B., ${ }^{3}$ Iyalabani, K. A. and ${ }^{4}$ Amusa, S. B. \\ Department of Agricultural Engineering, Ladoke Akintola University of Technology, P.M.B 4000 Ogbomoso, Oyo State, \\ Nigeria
}

\section{Abstract}

Corresponding author's E-mail: amusabs2009@gmail.com

Maize is known to be an important crop for food security in developing countries; and farmers have continued to experience post-harvest losses which lead to reduction in the quality or quantity of maize grains. The main causes of post-harvest losses are the storage insect, pests, improper drying and poor storage systems. Poor storage accounts for 5-10\% loss and 5\% loss is attributed to insect attacks. This research modified a one tonne metallic silo with the aim of studying the effects on moisture content and hectolitre weight of the maize grains. The moisture content was determined using moisture meter while the hectolitre weight was determined using extruded brass material. The study lasted for six months and analyses were carried out on the data collected using Duncan multiple range tests at $95 \%$ level of confidence. The moisture content was observed to reduce from $13.5 \%$ to $11.4 \%$ w.b while hectoliter weight which is the main determinant of the market value of the grain was observed to increase from $276 \mathrm{~kg} / \mathrm{ml}$ to $288 \mathrm{~kg} / \mathrm{ml}$, this implies that there was increase in the cost value of the grain after six month of storage. The results showed that variations in moisture content along storage period were significant at $(p \leq 0.05)$

Keyword: Hectoliter weight, Moisture content, Metallic silo, Maize.

\section{Introduction}

Maize (Zeal mays L.) is one of the most important cereal crops providing calories to over 4.5 billion people in about 94 developing countries including Nigeria (Von Braun et al., 2010). Maize is third in ranking as the world's most traded cereal with $50 \%$ of it being grown in developing countries (Abbassian, 2006; UNDP, 2010). Maize is becoming the miracle seed for Nigerian and economic development, as it has established itself as a very significant component of the farming system particularly in the Northern states of Nigeria (Ahmed, 2006). Maize is a principal crop in Sub-Saharan Africa with 35 million tons produced on about 2.5 million hectares yearly (Tefera et al., 2011a). Although, maize is primarily grown for livestock and industrial use in the developed world, it is a stable food for human consumption in Africa. It provides food and income to more than 300 million small farm holder in Africa and other developing countries (Tefera et al., 2011a). Maize is recognised to be important for securing food in developing countries; farmers have continued to experience post-harvest losses which lead to reduced quality or quantity of maize grains. The main causes of post-harvest losses are the storage insect and pests, improper drying and poor storage systems. Poor storage accounts for about 5-10\% loss and 5\% loss is attributed to insect attacks (Bett and Nguyo, 2007). In Africa, the main storage pests of maize are the maize weevil and the larger grain borer (Abebe et al., 2009, Bett and Nguyo, 2007; Kimenju and De Groote, 2010; Tefera et al., 2011b). Maize production is seasonal resulting in fluctuation of its supply which does not match the stable demand all year round. Grain storage serves an important role in stabilizing prices by taking the produce off market during peak season and releasing it when the grain is in short supply (Proctor, 1994). Improved storage therefore becomes important aspect of household food security and rural livelihood since it ensures continuous stable supply of food and better farm income (Thamaga-chitja et al., 2004). The successful storage of grain is largely based on two important qualitative factors; the ability to stabilize the moisture content to prevent the growth of mud and to maintain the hectoliter weight of the grain. The hectoliter weight is defined as the ability of the grain to be able to form powder; this is also referred to as flour efficiency of the grain. These qualitative factors are the determinant of the economic value of grains. Hence, this study modified an existing metallic silo and evaluates the quality of maize grains stored in a modified metallic silo. 


\section{Materials and methods}

Materials used for this research were yellow maize (zea mays), phostoxin, coopex dust and celophine nylon while the laboratory equipment used were, one tonne capacity metallic silo, moisture metre produced by Fermex with Moisture accuracy of \pm 0.5 Moisture repeatability of $0.2 \%$ depending on the grain type, Moisture resolution: $0.1 \%$ moisture and fermex hectolitre weight cup of Repeatability: $0.6 \mathrm{~kg} / \mathrm{hl}$ in commercial trade range test weight resolution: $0.1 \mathrm{Ib} / \mathrm{bu}(\mathrm{kg} / \mathrm{hl})$. The metallic silo is cylindrical in shape and manufactured from galvanized steel. It has two openings, the upper lid and the grain outlet. The upper lid has an opening with a cover as intake through which the grains were loaded into the silo. The bottom part of the silo has an outlet with cover through which stored grains could be discharged. Probes were constructed on the silo, three on each adjacent side. These probes were paced at varying heights of Probe A $=61 \mathrm{~cm}$, Probe $\mathrm{B}=122 \mathrm{~cm}$ and Probe $\mathrm{C}=183 \mathrm{~cm}$ above the bottom of the metallic silo, the silo was kept under a roof to avoid direct sunlight radiation (figure 1 and 2). Yellow maize grains were used for the study; it was winnowed to remove any form of foreign materials and broken kennels before being transferred into the silo. Phostoxine has been found effective against grains insect and their pre adult stage. It is applied 25 tablet per tonne. The active ingredients contained by the phostoxine tablet are Aluminium phosphide (56\%, inert ingredients: $44 \%$ ), this was done to prevent insect infestation inside the silo. Coopex dust is in a powdered form applied evenly at the rate of $1 \mathrm{~kg}$ per tonne. The active ingredient in coopex dust is permethrin $0.5 \%$. Before the filling of the silo, the yellow maize grains were allowed to cool to ambient temperature. The cleaned maize was maintained at 13\% (w.b.) moisture content. Both the inner and outer parts of the metallic silo were cleaned after which it was also checked for leakages and later placed on a metal stand platform to avoid contact with the ground. The moisture content was determined using fermex moisture meter. The hectoliter device is made of extruded brass material. The whole numbers located at the bottom of the device, the diameter, length, interior volume of the holes were in accordance with the British Imperial bushel standards. while the hectolitre weight was determined using equation 1 (FAO, 2010), the study lasted for six months and analyses were carried out on the data collected using Duncan multiple range test at $95 \%$ confidence level

$$
\mathrm{HLW}=\frac{\text { mass of grain sample in cylinder }}{\text { volume of hectolitre cylinder }(250 \mathrm{ml})} \times \frac{100}{1}
$$

\section{Results and discussion}

Table1 compared the moisture contents of the various probes along the storage period. The highest moisture content (w.b.) at the first month of the study was obtained at the bottom probe A with an average mean of 13.67 while the lowest was probe B with an average mean of 12.50. The moisture content reduces along all probes throughout the six months of study and at the end of the study the moisture content across all probes was observed to have an average means of $11.00 \%$ (w.b). The results suggested that irrespective of the level (probe) grain moisture content appears to decrease steadily throughout the period of storage with the $6^{\text {th }}$ month having the lowest moisture content of $11.00 \%$ (w.b). Table 1 shows the decreasing order exhibited by hectoliter weight with response to the storage period. 


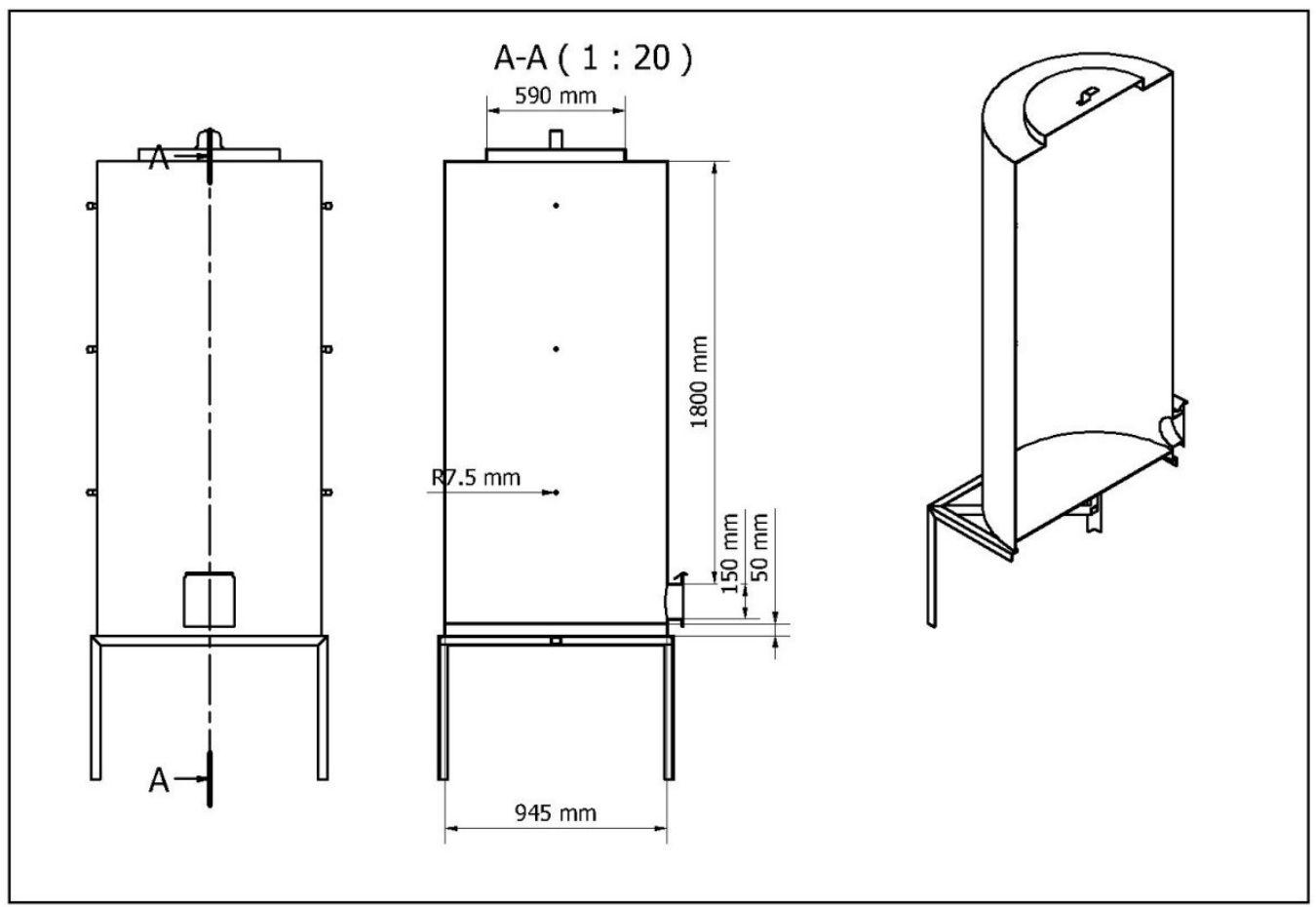

Figure 1: Sectional View of the Silo.

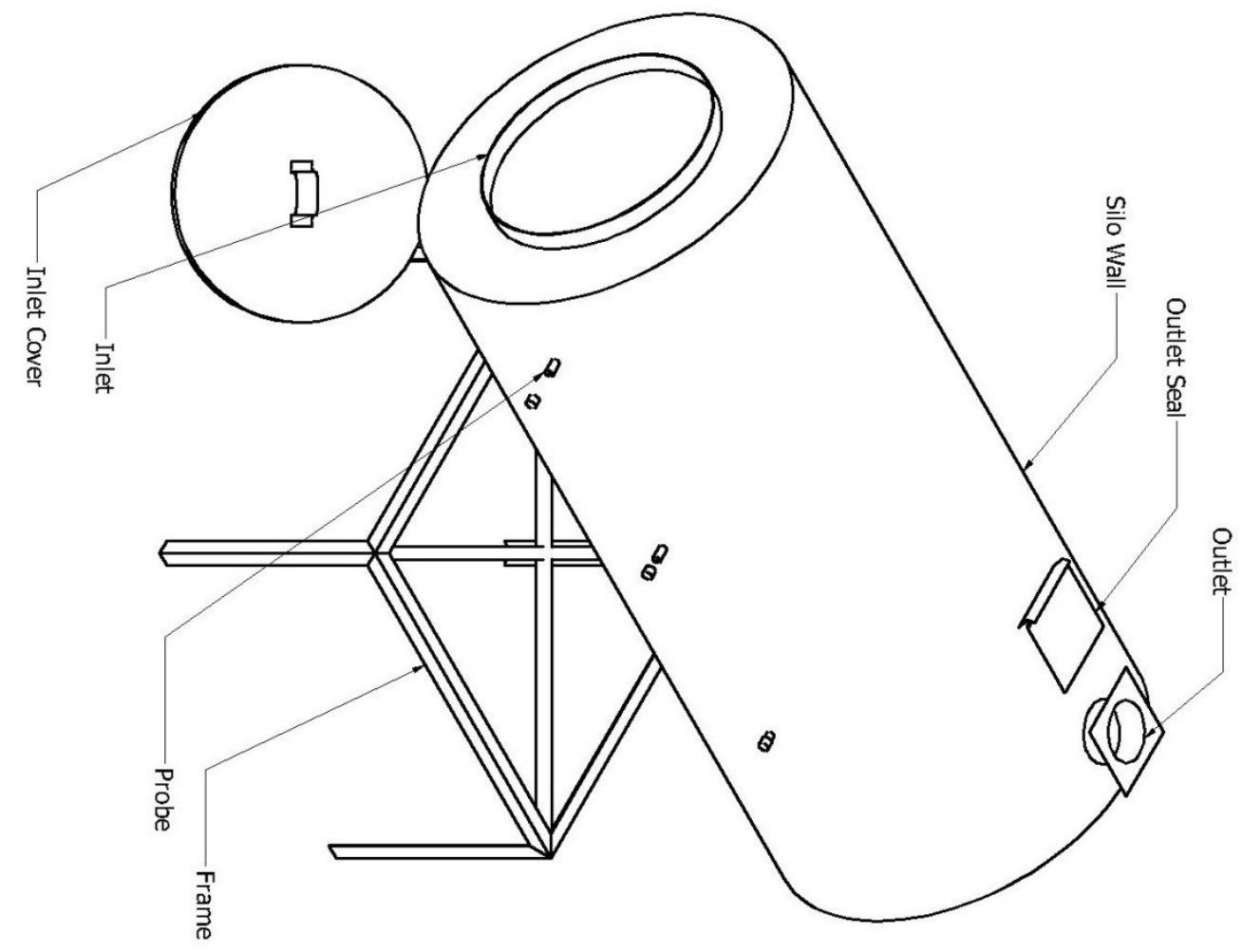

Figure 2: Isometric view of the silo. 
The mean values obtained from the statistical analysis across the probes $\mathrm{A}, \mathrm{B}$, and $\mathrm{C}$ at $95 \% \mathrm{CI}$ was $13.23,12.53$ and 13.40 for the first month and the subsequent month reduced slightly. Table 2 shows that the hectolitre decreases from the first month of storage to the third, ranging from 276, 272 and $268 \mathrm{~kg} / \mathrm{hl}$ and thereafter increases steadily from the fourth month through the sixth month ranging from 280, 284 and $288 \mathrm{~kg} / \mathrm{hl}$. This suggests that hectolitre increases with length of storage. This result is in line with the findings of (Sawan et al.,2012). Sawant et al. (2012) reported that moisture content of grains stored showed decreasing trend with respect to the storage period. This may be due to the lack of insect infestation which increases the moisture during the respiration. However, in the present study the decreased in moisture content with respect to storage period could be attributed to the air tight silo condition.

Table 1: Summary statistics for storage period and surface and grains moisture content

\begin{tabular}{|c|c|c|c|c|c|c|c|}
\hline \multirow{2}{*}{\multicolumn{2}{|c|}{ Period of Storage }} & \multirow{3}{*}{$\frac{\text { Mean }}{13.67}$} & \multirow{3}{*}{$\frac{\mathrm{SD}}{0.15}$} & \multicolumn{2}{|c|}{$95 \% \mathrm{CI}$} & \multirow[b]{2}{*}{ Min } & \multirow{3}{*}{$\frac{\text { Max }}{13.80}$} \\
\hline & & & & \multirow{2}{*}{$\frac{\mathrm{LB}}{13.29}$} & \multirow{2}{*}{$\frac{\mathrm{UB}}{14.05}$} & & \\
\hline 1st Month & Bottom & & & & & 13.50 & \\
\hline & Probe A & 13.23 & 0.25 & 12.61 & 13.86 & 13.00 & 13.50 \\
\hline & Probe B & 12.53 & 0.15 & 12.15 & 12.91 & 12.40 & 12.70 \\
\hline & Probe $\mathrm{C}$ & 13.40 & 0.17 & 12.97 & 13.83 & 13.20 & 13.50 \\
\hline \multirow[t]{4}{*}{ 2nd Month } & Bottom & 14.40 & 0.26 & 13.74 & 15.06 & 14.10 & 14.60 \\
\hline & Probe A & 13.43 & 0.12 & 13.15 & 13.72 & 13.30 & 13.50 \\
\hline & Probe B & 12.47 & 0.15 & 12.09 & 12.85 & 12.30 & 12.60 \\
\hline & Probe C & 13.33 & 0.15 & 12.95 & 13.71 & 13.20 & 13.50 \\
\hline \multirow[t]{4}{*}{ 3rd Month } & Bottom & 13.43 & 0.15 & 13.05 & 13.81 & 13.30 & 13.60 \\
\hline & Probe A & 12.77 & 0.15 & 12.39 & 13.15 & 12.60 & 12.90 \\
\hline & Probe B & 13.23 & 0.06 & 13.09 & 13.38 & 13.20 & 13.30 \\
\hline & Probe $\mathrm{C}$ & 13.33 & 0.15 & 12.95 & 13.71 & 13.20 & 13.50 \\
\hline \multirow[t]{4}{*}{ 4th Month } & Bottom & 11.60 & 0.10 & 11.35 & 11.85 & 11.50 & 11.70 \\
\hline & Probe A & 12.77 & 0.15 & 12.39 & 13.15 & 12.60 & 12.90 \\
\hline & Probe B & 12.33 & 0.12 & 12.05 & 12.62 & 12.20 & 12.40 \\
\hline & Probe C & 11.90 & 0.10 & 11.65 & 12.15 & 11.80 & 12.00 \\
\hline \multirow[t]{4}{*}{ 5th Month } & Bottom & 11.30 & 0.10 & 11.05 & 11.55 & 11.20 & 11.40 \\
\hline & Probe A & 12.53 & 0.12 & 12.25 & 12.82 & 12.40 & 12.60 \\
\hline & Probe B & 12.23 & 0.06 & 12.09 & 12.38 & 12.20 & 12.30 \\
\hline & Probe $\mathrm{C}$ & 11.67 & 0.15 & 11.29 & 12.05 & 11.50 & 11.80 \\
\hline \multirow[t]{4}{*}{ 6th Month } & Bottom & 10.83 & 0.21 & 10.32 & 11.35 & 10.60 & 11.00 \\
\hline & Probe A & 11.57 & 0.21 & 11.05 & 12.08 & 11.40 & 11.80 \\
\hline & Probe B & 11.40 & 0.20 & 10.90 & 11.90 & 11.20 & 11.60 \\
\hline & Probe $\mathrm{C}$ & 11.07 & 0.15 & 10.69 & 11.45 & 10.90 & 11.20 \\
\hline
\end{tabular}

LB: lower bound of the $95 \%$, UB: upper bound of the $95 \%$, SD: standard deviation 
Table 2 Grains moisture content and hectolitre weight

Month Moisture content(w.b. \%) $\quad$ Hectolitre (kg/ml)

September

October

November

December

January

February

Table 3 shows the effect of storage period on moisture content of grain obtained at various probes. The results showed that variations in moisture content along storage period were significant at $(p \leq 0.05)$. The moisture content along storage period for the different probes were observed not to be equal. This means that variations observed in moisture content for the different storage period were actually due to effect of storage period and not by random occurrence alone. Grain moisture content does not differ significantly across probes.

Table 3: Effect of storage period on maize grain moisture

\begin{tabular}{lllllll}
\hline & & Sum of Squares & Df & Mean Square & F & Sig. \\
\hline Bottom & Between Groups & 32.583 & 5 & 6.517 & 217.219 & 0.001 \\
& Within Groups & 0.360 & 12 & 0.030 & & \\
& Total & 32.943 & 17 & & & \\
\hline Probe A & Between Groups & 6.425 & 5 & 1.285 & 42.833 & 0.001 \\
& Within Groups & 0.360 & 12 & 0.030 & & \\
& Total & 6.785 & 17 & & & \\
\hline Probe B & Between Groups & 5.227 & 5 & 1.045 & 58.800 & 0.001 \\
& Within Groups & 0.213 & 12 & 0.018 & & \\
& Total & 5.440 & 17 & & & \\
\hline Probe C & Between Groups & 15.878 & 5 & 3.176 & 142.905 & 0.001 \\
& Within Groups & 0.267 & 12 & 0.022 & & \\
& Total & 16.145 & 17 & & & \\
\hline Hectorlitre & Between Groups & 593.778 & 5 & 118.756 & 16.700 & 0.001 \\
& Within Groups & 85.333 & 12 & 7.111 & & \\
& Total & 679.111 & 17 & & & \\
\hline
\end{tabular}

D.f : degree of freedom Sig : level of significance $(p \leq 0.05)$

This implies that irrespective of the probes, grain moisture content were relatively the same on the average along the storage month. Storage period also had significant effect on hectoliter implying that hectoliter observed for the six months of storage also differs significantly from one storage month to the other on the average. This significant difference in hectolitre weight can be related to the decrease in moisture content; zero insect infestation and mould growth brought about decrease in moisture content. 
This result agrees with Sawant et al. (2012) who worked on the effect of temperature, relative humidity and moisture content on germination percentage of wheat stored in different storage structures. According to Rankin (2009), he work on understanding corn test weight and reported that a decrease in moisture content of grain will increase the hectoliter weight of the grain. The reason being that as grains dry, it also shrinks allowing for more grains to pack in a test container. This means hectolitre weight has an inverse relationship with moisture content. It also follows that high moisture content grains will result in lower hectolitre. This reduction is mostly due to swelling of the kernels and partly due to the roughening of the bran coat (Lloyd et al.,1999). Swelled kernels have more volume and this reduces the number of grains that will fit into the test container.

\section{Conclusion}

The study concluded that there was no deterioration in the grain stored throughout the storage period, the moisture content was observed to reduce from $13.5 \%$ to $11.4 \% \mathrm{w}$. $\mathrm{b}$ while hectoliter weight of the grain was observed to increase from $276 \mathrm{~kg} / \mathrm{ml}$ to $288 \mathrm{~kg} / \mathrm{ml}$,

\section{Reference}

Abbassian, A. (2006). Maize: International Market Profile. Conference Paper Presentation in Food and Agriculture Organisation, Rome.

Abebe, F., Tefera, T. Mugo, S. Beyene, Y. and Vidal, S.(2009). Resistance of maize varieties to the maize weevil Sitophilus zea mais (Motsch.) (Coleoptera: Curculionidae). African Journal of Biotechnology 8:5937-5943.

Ahmed, B. (2006). Economic analysis of Fertilizer used in Maize Production in the Northern Guinea Savannah of Nigeria. Unpublished Ph.D Thesis, Department of Agric. Economics and Rural Sociology, Ahmadu Bello University, Zaria; Nigeria.pp45-60

Bett, C., and Nguyo, R. (2007). Post-harvest storage practices and techniques used by farmers in semiarideastern and central Kenya, El-Minia, and Egypt.pp5-25

FAO (2010) Technical cooperation Programme Assistance to Strategic Grain Reserve Scheme in Nigeria. Technical Statement prepared for the Government of Nigeria. FAO of the United Nation Rome, Italy.http://columbia.uwex.edu/ag/documents/CornTW09.pdf. 12 March 2010

Kimenju, S.C., and H. De Groote.(2010). Economic Analysis of Alternative Maize Storage Technologies inKenya Cape Town, South Africa. African Association of Agricultural Economists (AAAE) and 48thAgricultural Economists Association of South Africa (AEASA)

Lloyd, B.J., Siebenmorgen, T.J., Bacon, R.K. and Vories, E. (1999). Harvest date andconditioned moisture effects on test weight of soft red winter wheat. American

Opportunities: A Scoping Paper.

Proctor, D.L., (1994). Grain storage techniques. Evolution and trends in developing countries. FAO Agricultural Services Bulletin No. 109. FAO, Rome.

Rankin,M.(2009).Understanding corn test weight. Crops and soils agent. University of Wisconsin.Crop and pest management.[WWW document].

Sawant, A. A., Patil, S. C., Kalse S. B. and Thakor N. J. (2012). Effect of temperature, relative humidity and moisture content on germination percentage of wheat stored in different storage structures. AgricEngInt: CIGR Journal Vol. 4 (2) http://www.Cigrjournal.org

Society of Agricultural Engineers, 15(5), 525-534.

Tefera, T.M., Stephen, B. Yoseph, K. Haron, and Regina, T.(2011a). Grain yield, stem borer and disease resistance of new maize hybrids in Kenya. African Journal of Biotechnology 10:4777-4783.

Tefera, T., Kanampiu, F. De Groote, H. Hellin, J. Mugo, S. Kimenju, S. Beyene, Y. Boddupalli, P.M. Shiferaw, B and Banziger. M. (2011b). The metal silo: An effective grain storage technology for 
LAUTECH Journal of Civil and Environmental Studies

Volume 3, Issue 1; September 2019

reducing post-harvest insect and pathogen losses in maize while improving smallholder farmers' food security in developing countries. Crop Protection 30:240-245.

Thamaga-Chitja, M.J.,Sheryl, L.H. Gerald, F.O and Maryann, G.( 2004). Impact of maize storage on ruralhousehold food security in Northern Kwazulu Natall. Tydskrifvir Gesinsekologieen Verbruikerswetenskappe 32

UNDP. (2010). Global Maize Production, Environmental Impacts and Sustainable Production

Von Braun, J.D., Byerlee, C. Chartres, T. Lumpkin, N. Olembo, and Waage, J. (2010). A Draft Strategy and Results Framework for the CGIAR. The World Bank, Washington D.C. 